НАУКОВИЙ ВІСНИІК

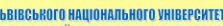
ИИНАРНӦ МЕДИЦИНИ ТА БОТТЕНОЛОО

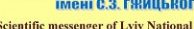

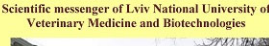

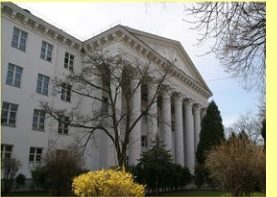

СЕРІЯ “ЕКОНОМІчн НАУКИ"

Том 21 № 93

2019
Науковий вісник Дьвівського національного університету ветеринарної медицини та біотехнологій імені С.3. Гжицького. Серія: Економічні науки

\author{
Scientific Messenger of Lviv National University \\ of Veterinary Medicine and Biotechnologies. \\ Series: Economical Sciences
}

\title{
Features of assessment of competitiveness of veterinary preparations
}

\author{
H.D. Harvas ${ }^{1,2}$, V.A. Kolodiichuk ${ }^{2}$ \\ ${ }^{1}$ State scientific research control institute of veterinary medicinal products and feed additives, Lviv, Ukraine \\ ${ }^{2}$ Stepan Gzhytskyi national university of veterinary medicine and biotechnologies Lviv, Ukraine
}

\section{Article info}

Received 17.09.2019

Received in revised form 21.10 .2019

Accepted 22.10.2019

State Scientific-Research Control Institute of Veterinary Medicinal Products and Feed Additives,

Donetska str., 11, Lviv,

79019, Ukraine.

Tel.: +38-097-188-71-55

E-mail:garvac@ukr.ua

Stepan Gzhytskyi National University of Veterinary Medicine and Biotechnologies Lviv,

Pekarska Str., 50, Lviv,

79010, Ukraine.
Harvas, H.D., \& Kolodiichuk, V.A. (2019). Features of assessment of competitiveness of veterinary preparations. Scientific Messenger of Lviv National University of Veterinary Medicine and Biotechnologies. Series: Economical Sciences, 21(92), 92-95. doi: 10.32718/nvlvet-e9318

For efficient production and obtain competitive advantages in the production market, an entity shall ensure in its competitiveness and to assess its prospects for the future. The company's management must have information on competitors and their ability to find a niche in the modern market process. The assessment of the competitiveness of the enterprise is based on a systematic analysis of internal and external factors and involves the use of appropriate tools for the demand and use of reserves to improve the efficiency of functioning of enterprises. The objects of analysis are the market environment for the functioning of sectoral enterprises, the legislative and regulatory framework governing the relations in the market of veterinary preparations.

Key words: competitiveness, enterprise, veterinary preparations, good manufacturing practice (GMP).

\section{Особливості оцінки конкурентоспроможності ветеринарних препаратів}

\author{
Г.Д. Гарвас ${ }^{1,2}$, В.А. Колодійчук ${ }^{2}$ \\ ${ }^{1}$ Державний науково-дослідний контрольний інститут ветеринарних препаратів та кормових добавок, \\ м. Львів, Украӥна \\ ${ }^{2}$ Львівський національний університет ветеринарної медицини та біотехнологій імені С.3. Гжиџького, м. Львів, \\ Україна
}

Для ефективного виробництва та одержання конкурентних переваг на ринку продукиї, суб'єкт господарювання, повинен впевнитись у свойй конкурентоспроможності і оцінити свою перспективу на майбутнє. Керівництву підприємства необхідно володіти інформацією щодо конкурентів, їх можливостей та знайти свою нішу в сучасному ринковому процесі. Оцінка конкурентоспроможності підприємства, здійснюється на основі системного аналізу внутрішніх $і$ зовнішніх факторів та передбачає використання відповідного інструментарію для попиту й задіяння резервів підвищення ефективності функціонування підприємств. Об'єктами аналізу є ринкове середовище функціонування галузевих підприємств, законодавча та нормативно-правова база, щз регламентує відносини на ринку ветеринарних препаратів.

Ключові слова: конкурентоспроможність, підприємство, ветеринарні препарати, належна виробнича практика (GМР).

\section{Вступ}

Для підвищення конкурентоспроможності вітчизняних підприємств галузі ветеринарної фармації в умовах євроінтеграції важливого значення набуває виробництво ветеринарних препаратів у відповідності до вимог міжнародних стандартів. Щоб забезпечити конкурентоспроможність продукції на внутрішньому і зовнішньому ринках вітчизняним підприємствам доцільно працювати за вимогами належної виробни- 
чої практики (GMP), що сприятиме інтегрованості ветеринарних препаратів України у світовий ринок 3 чітко регламентованими принципами, правилами i стандартами (Kosenko et al., 2014).

Питання конкурентоспроможності галузі ветеринарної фармації, незважаючи на теоретичний доробок ще недостатньо опрацьовано вітчизняною наукою в силу своєї складності та багатоплановості. Питання управління конкурентоспроможністю галузевих підприємств висвітлено в працях вітчизняних і зарубіжних вчених, а саме: Г. Азоєва, I. Ансоффа, I. Бушуєвої, П. Вербицького, О. Гаврилюк, В. Величка та ін. Однак ці дослідження не враховують специфіки, виробництва і обігу ветеринарних препаратів ринок яких динамічно розвивається, тож проблематика конкурентоспроможності цієї продукції завжди актуальна і на часі (Harvas, 2019).

Крім того, сьогодні у законодавстві ветеринарної фармації України впроваджується Директива 2001/82/СС щодо Кодексу Співтовариства для ветеринарних лікарських препаратів де прописано, що процес виробництва має відповідати вимогам Директиви Комісії 91/412/СЕС про встановлення принципів та настанов для ветеринарних лікарських засобів, а також принципів та настанов GMP, що регламентують лікарські засоби в Європейському Союзі (Directive 2001/82/EC). Все це потребує додаткових досліджень яким і присвячена стаття.

Мета роботи - дослідити та удосконалити методичні підходи до оцінки конкурентоспроможності підприємств-виробників галузі ветеринарної фармації.

\section{Матеріал і методи досліджень}

В процесі нашого дослідження використовували метод контент-аналізу офіційних даних інтернетресурсів зокрема, Законодавство України, матеріали: Мінагрополітики України, Держпродспоживслужби, ДНДКІ ветпрепаратів та кормових добавок. Методом монографії провели анкетування кваліфікованих спеціалістів з виробництва ветеринарних препаратів.

\section{Результати та їх обговорення}

Важливим етапом в оцінці конкурентних переваг виробництва ветеринарних препаратів набуває використання економічних методів і прийомів, з метою виявлення та усунення недоліків у виробничозбутовій діяльності підприємств. Щодо конкурентоспроможності самого підприємства то його оцінюють за показниками економічного потенціалу (основний капітал, обсяг продажів, рентабельність, прибуток, і т. п.); постачальницько-збутового потенціалу (асортимент продукції, наявність товарних запасів, рівень технології процесу збуту тощо); репутації підприємства; фінансового становища (структура капіталу, платоспроможність, кредитоспроможність, тощо); організаційної структури; менеджмент організації, кваліфікацію керівних працівників, обраної ринкової стратегіï, тощо.
Сучасний ринок ветеринарних препаратів, який постійно розширюється за кількісними і асортиментними показниками, стає економічно привабливим бізнесом. Збільшення кількості суб'єктів господарювання та обсягів виробництва ветеринарних препаратів підвищує ринкову конкуренцію та спонукає виробників до пошуку і використання нових стратегій й шляхів у завоюванні конкурентних позицій на ринку. Таким чином ринок ветеринарної фармації України можна охарактеризувати як ринок специфічної продукції високих наукоємностей з різноманітним асортиментом товарів та нееластичним попитом, що залежить від епідемій, кількості поголів'я галузей тваринництва і птахівництва та інших специфічних факторів (Harvas, 2019).

За оцінками Мінагрополітики України у 2018 році в галузі ветеринарної фармації підлягають ліцензуванню 15 великих, 20 середніх і понад 25 малих підприємств. За даними Держпродспоживслужби станом на 10.10.2019 року видано ліцензії на провадження виробництва ветеринарних препаратів 45-ти підприємствам. Окрім вітчизняних підприємств-виробників на ринку ветеринарних препаратів України реалізують свою продукцію понад 70 зарубіжних підприємств з 40 країн світу. Станом на 01.10.2019 року в Україні зареєстровано 54\% ветеринарних препаратів вітчизняного виробництва, 46\% - зарубіжних.

На наш погляд, одним 3 найголовніших критеріїв забезпечення конкурентоспроможності суб'єкту ринку ветеринарної продукції є впровадження європейських вимог належної виробничої практики (GMP). Належна практика виробництва ветеринарних препаратів - це система, яка стосується всіх аспектів виробничого процесу, для забезпечення узгодженого виробництва та контролю згідно із стандартами якості 3 метою мінімізації ризиків, пов'язаних 3 виробництвом, які не можуть бути усунуті шляхом перевірки кінцевого продукту. Така практика базується на міжнародних стандартах, принципах та рекомендаціях і $є$ необхідною для забезпечення дотримання відповідних ветеринарно-санітарних заходів, технічних регламентів та інших вимог. Однак впровадження GMP у виробництво вітчизняних ветеринарних препаратів потребує значних фінансових ресурсів, відповідної кваліфікації персоналу та сучасного обладнання.

Сама система GMP є загальновизнаною у світі щодо забезпечення якості лікарських засобів, як в гуманній так і ветеринарній медицині та є невід'ємною складовою підвищення рівня конкурентоспроможності фармацевтичного виробництва. Це підтверджує досвід функціонування провідних підприємств, таких як: ТОВ НУНВФ "Бровафарма", АТ “Біофарм”, ТОВ "Ветсинтез", ПрАТ “ВНП "Укрзооветпромпостач", ПП “O.L.KAR - АгроЗооВетСервіс", ТОВ “Укрветпромпостач” та інших, в яких умови виробництва максимально наближені до вимог GMP за рахунок чого забезпечують собі конкурентні позиції широким асортиментом продукції на ринку (табл. 1). 


\section{Таблиця 1}

Підприємства-виробники з найбільшим асортиментом продукції ветеринарної фармації України

\begin{tabular}{ccc}
\hline $\begin{array}{c}\text { № } \\
\text { п/н }\end{array}$ & Вітчизняні підприсмства-виробники ветеринарних препаратів & $\begin{array}{c}\text { Кількість ветеринарних препаратів пред- } \\
\text { ставлених в обіг (од. найменувань)* }\end{array}$ \\
\hline 1. & ПП “О.L.КАR -АгроЗооВетСервіс" & 260 \\
2. & ПрАТ ВНП “Укрзоветпромпостач” & 170 \\
3. & ТОВ ВФ “Базальт” & 160 \\
4. & ТОВ НУНВФ “Бровафарма” & 130 \\
5. & ПП фірма “Фарматон” & 125 \\
6. & ТОВ “Ветсинтез” & 111 \\
7. & ТОВ “БіоТестЛаб” & 99 \\
8. & ТОВ фірма “Продукт” & 66 \\
9. & ТОВ “Укрветпромпостач” & 65 \\
10. & АТ “Біофарм” & 49 \\
\hline
\end{tabular}

*Дані взяті з офіційних веб-сайтів підприємств-виробників ветеринарних препаратів

Згідно з табличними даними загальна кількість представлених ветеринарних препаратів на ринок ветеринарної продукції 10-ма вітчизняними виробниками складає 1235 одиниць найменувань. Однак серед тієї кількості лише 85\% препаратів є зареєстрованими в Україні, а решта $15 \%$ реалізується 3 порушенням Закону України "Про ветеринарну медицину", за ст. 67 про заборону обігу ветеринарних препаратів, не зареєстрованих в Україні. Це пов'язано з тим що в Україні з 2014 р. діяв мораторій на проведення перевірок бізнесу, фактично було призупинено виконання державних програм щодо забезпечення контролю i нагляду за якістю лікарських засобів для ветеринарної медицини, відповідно допущення в обіг незареєстрованої продукції.

Таким чином виробники продукції галузі ветеринарної фармації, уникаючи процедури реєстрації економлячи на витратах, за рахунок чого підвищують цінові параметри конкурентоспроможності, що створює ризики потрапляння на ринок неякісної продукції. Процедура реєстрації (рис. 1) ветеринарних препаратів вимагає певних затрат, але при цьому гарантує забезпечення якісних параметрів продукції і покращення іiї конкурентоспроможності.
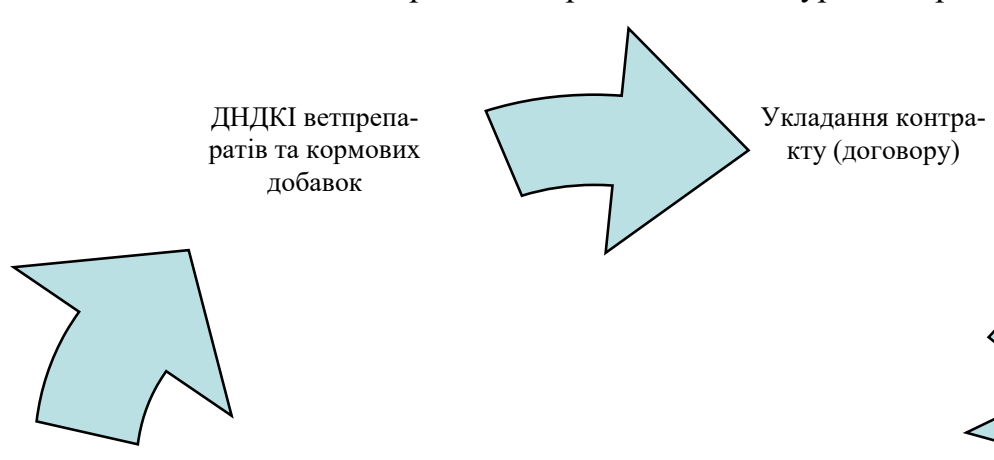

$$
\begin{gathered}
\text { Подання заявником } \\
\text { реєстраційного } \\
\text { досьє (РД) на } \\
\text { ветеринарний } \\
\text { препарат }
\end{gathered}
$$

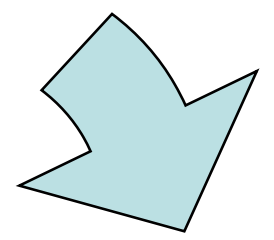

НДКІ ветпрепата кормових добавок
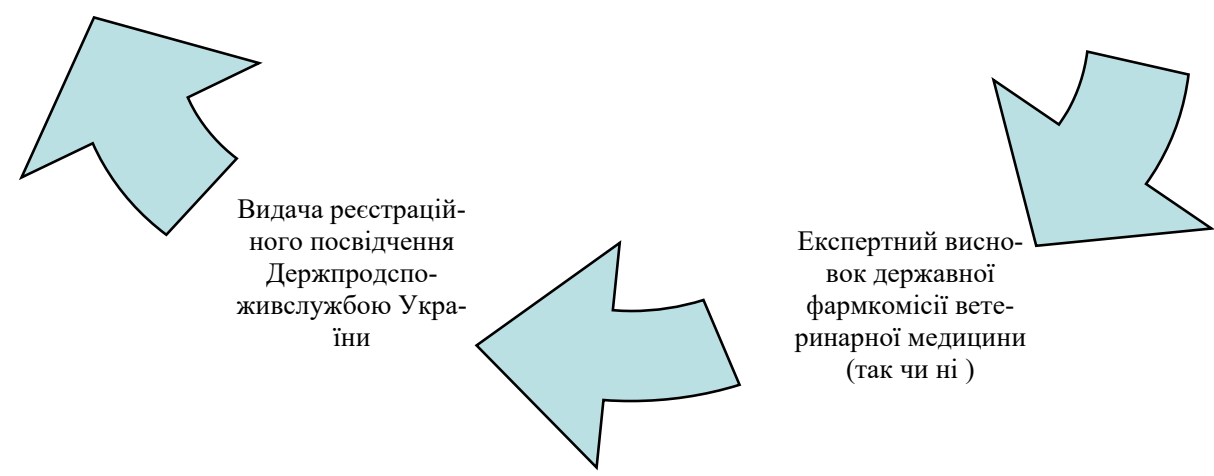

вок державної фармкомісії ветеринарної медицини (так чи ні )

Рис. 1. Схема державної реєстрації ветеринарної продукції яка сьогодні діє в Україні 
Ми провели соцопитування виробників ветеринарних препаратів щодо формування пропозиції за на- ступними критеріями та одержали відповідні результати за 5-ти бальною шкалою (табл. 2).

\section{Таблиця 1}

Соцопитування виробників ветеринарних препаратів щодо формування пропозиції за критеріями

\begin{tabular}{clc}
\hline № з/п & \multicolumn{1}{c}{ Критерій } & Оцінка \\
\hline а) & вартість ветеринарного препарату & 3 \\
б) & швидкість дії ветеринарного препарату (ефективність) & 5 \\
в) & безпечність для тварин та їх власників & 4 \\
г) & тривалість курсу лікування & 3 \\
д) & зручність у застосуванні (лікарська форма) & 4 \\
е) & привабливість дизайну упакування & 4 \\
є) & імідж виробника & 3 \\
ж) & частота приймання ветеринарного препарату & 2 \\
з) & необхідність повторення курсу лікування & 1 \\
и) & рівень новизни ветеринарного препарату & 2 \\
і) & країна-виробник & 3 \\
\hline
\end{tabular}

3 результатів опитування зрозумілим є те, що критерій якості на ринку ветеринарних препаратів $\epsilon$ більш вагомий за критерій ціни (табл. 2), саме дотримання виробництва за вимогами GMP та реєстрація галузевої продукції, забезпечує підвищення загальної конкурентоспроможності.

Отже для підвищення рівня конкурентоспроможності підприємства, ефективного збільшення його ринкової частки та покращення фінансовоекономічного стану пропонуємо дотримуватись наступних шляхів:

a) впровадити систему управління якості на підприємстві, яка допомагатиме ефективно управляти якістю продукції, оцінювати і підвищувати їі;

б) дотримуватись вимог GMP на всіх етапах виробництва ветеринарних препаратів;

в) обов'язково дотримуватись процедури реєстрації ветеринарних препаратів в Україні;

г) впроваджувати інноваційні розробки у власне виробництво (новий ветеринарний препарат);

д) встановити конкурентоспроможну ціну (ветеринарний препарат повинен зарекомендувати себе на ринку товарів за доступною ціною для споживача);

е) забезпечити рекламну підтримку своєї продукції через інтернет-сайти, аптеки, виставки, тренінгсемінари, та дистрибуційну мережу.

\section{Висновки}

Гармонізація основних вітчизняних технічних вимог у виробництві ветеринарної продукції згідно вимог $\mathrm{CC}$, забезпечує конкурентоспроможність галузевих підприємств і може бути заходом для захисту виробників ветеринарних препаратів від недобросовісних конкурентів 3 неякісною чи фальсифікованою продукцією.

Результати дослідження підтверджують, належний рівень конкурентоспроможності національної ветеринарної фармації стимулює підприємства ветмедицини до розширення асортименту якісних і безпечних вете- ринарних препаратів та їх постачання в обіг, що позитивно впливатиме на фінансовий стан підприємств та їх модернізацію.

\section{References}

Derzhprodspozhyvsluzhba. Elektronnyi resurs: http://www.consumer.gov.ua (in Ukrainian).

Directive 2001/82/EC of the European Parliament and of the Council of 6 November 2001 on the Community code relating to veterinary medicinal products (Official Journal L 311, 28/11/2001 P. 1-66).

DNDKI vetpreparativ ta kormovykh dobavok. Elektronnyi resurs: http://www.scivp.lviv.ua (in Ukrainian).

Good Manufacturing Practice for Pharmaceutical Products: Main Principles (2003). World Heals Organization technical Report Series, 908, 120.

Harvas, H.D. (2019). Zakonodavchi rehuliatorni aspekty rynku produktsii veterynarnoi farmatsii Yevropeiskoho Soiu-zu. Naukovyi visnyk LNU veterynarnoi medytsyny ta biotekhnolohii imeni S. Z. Gzhytskoho. Seriia: Ekonomichni nauky, 21(92), 137-140. doi: 10.32718/nvlvet-e9223 (in Ukrainian).

Kosenko, Yu.M., Zaruma, L.Ye., Kalynovska, L.V., Stefanyshyn, H.S., \& Shkilnyk, O.S. (2014). Vyrobnytstvo veterynarnykh preparativ za pryntsypamy nalezhnoi vyrobnychoi praktyky (GMP) - stratehiia harantii yakosti ta vidpovidnosti do vymoh mizhnarodnykh standartiv. Naukovo-tekhnichnyi biuleten Instytutu biolohii tvaryn i Derzhavnoho naukovo-doslidnoho kontrolnoho instytutu vetpreparativ ta kormovykh dobavok, 15(2-3), 340-345. http://nbuv.gov.ua/UJRN/ Ntbibt $2014 \quad 15 \quad 2-3 \quad 67$ (in Ukrainian).

Minahropolityka ${ }^{-}$Ukrainy. Elektronnyi resurs: https://minagro.gov.ua (in Ukrainian).

Zakon Ukrainy "Pro veterynarnu medytsynu". Elektronnyi resurs: https://zakon.rada.gov.ua/ laws/show/2498-12 (in Ukrainian). 